\title{
Juvenile Adamantiades-Behçet Disease
}

\author{
Aristeidis G. Vaiopoulos ${ }^{a}$ Meletios A. Kanakis ${ }^{c}$ Violetta Kapsimali ${ }^{d}$ \\ Georgios Vaiopoulos ${ }^{c}$ Phedon G. Kaklamanis ${ }^{\mathrm{e}}$ Christos C. Zouboulis $^{\mathrm{b}}$ \\ ${ }^{a}$ Institute of Pathology, University of Würzburg, Würzburg, and ${ }^{b}$ Departments of Dermatology, \\ Venereology, Allergology and Immunology, Dessau Medical Center, Dessau, Germany; ${ }^{C}$ Institute of \\ Experimental Physiology and ${ }^{\mathrm{d}}$ Department of Microbiology, Medical School, University of Athens, and \\ ${ }^{\mathrm{e}}$ Athens Medical Center, Athens, Greece
}

\section{Key Words}

Aphthae $\cdot$ Childhood $\cdot$ Epidemiological study $\cdot$ Genitoanal region · Adamantiades-Behçet disease · Behçet's disease · Uveitis

\begin{abstract}
Adamantiades-Behçet disease (ABD) is a chronic, multisystemic, recurrent, inflammatory vascular disorder of unknown etiology. Patients with symptoms initially appearing at the age of 16 or less are considered as cases of juvenile-onset $A B D$ (JABD). JABD is relatively rare compared to $A B D$ of adults, and only case reports and case studies have been published regarding this subtype of the disease. Epidemiology, clinical features, diagnosis and treatment of JABD are discussed in this review.

๑) 2016 S. Karger AG, Basel
\end{abstract}

\section{Introduction}

Adamantiades-Behçet disease (ABD) is a chronic, multisystemic, recurrent, inflammatory vascular disorder of unknown etiology [1,2]. Genetic or environmental factors as well as immunological aberrations have been incriminated by various investigators for its etiopathogenesis, still without a clear outcome to date $[1,3]$. It is a worldwide disease with a predilection for people living in the Far East, Middle East and the Mediterranean regions (former socalled Silk Route). ABD affects people of all ages, showing the highest prevalence of onset in the third decade of life. Both genders may be involved, though its clinical spectrum and severity display quite substantial differences between them $[4,5]$. Patients with symptoms occurring up to the age of 16 are considered as cases of juvenile-onset $\mathrm{ABD}$ (JABD) $[6,7]$.

JABD is relatively rare compared to its adult counterpart (AABD). Since the publication of the first article on the pediatric disease by Mundy and Miller in 1978 [8], several case reports and case studies have been described $[6,7,9-14]$. However, reviews on this subject are rather scarce $[6,15-18]$.

\section{Epidemiology}

The epidemiology of JABD is difficult to estimate also because there is no formal agreement on either the age at the disease onset or the age at which the symptoms meet the older or current diagnostic and classification criteria $[19,20]$.

\section{KARGER}

E-Mail karger@karger.com

www.karger.com/drm
(C) 2016 S. Karger AG, Base

$1018-8665 / 16 / 2322-0129 \$ 39.50 / 0$
Prof. Dr. med. Prof. h.c. Dr. h.c. Christos C. Zouboulis

Departments of Dermatology, Venereology, Allergology and Immunology Dessau Medical Center

Auenweg 38, DE-06847 Dessau (Germany)

E-Mail christos.zouboulis@ klinikum-dessau.de 
Table 1. Comparison of clinical features of JABD

\begin{tabular}{|c|c|c|c|c|c|c|c|c|c|c|}
\hline & $\begin{array}{l}\text { Kim } \\
\text { et al. [21], } \\
\text { 1994, } \\
\text { Korea }\end{array}$ & $\begin{array}{l}\text { Fujikawa } \\
\text { and Suemitsu } \\
{[31], 1997,} \\
\text { Japan }\end{array}$ & $\begin{array}{l}\text { Hung } \\
\text { et al. [33], } \\
2013 \text {, } \\
\text { Taiwan }\end{array}$ & $\begin{array}{l}\text { Davatchi } \\
\text { et al. [29], } \\
\text { 2010, Iran }\end{array}$ & $\begin{array}{l}\text { Atmaca } \\
\text { et al. [15], } \\
\text { 2011, } \\
\text { Turkey }\end{array}$ & $\begin{array}{l}\text { Sungur } \\
\text { et al. [14], } \\
2009 \text {, } \\
\text { Turkey }\end{array}$ & $\begin{array}{l}\text { Karincaoglu } \\
\text { et al. [7], } \\
\text { 2008, } \\
\text { Turkey }\end{array}$ & $\begin{array}{l}\text { Vaiopoulos } \\
\text { et al. [32], } \\
\text { 1999, } \\
\text { Greece }\end{array}$ & $\begin{array}{l}\text { Koné-Paut } \\
\text { et al. [30], } \\
\text { 1998, } \\
\text { France }\end{array}$ & $\begin{array}{l}\text { Treudler } \\
\text { et al. [6], } \\
\text { 1999, } \\
\text { Germany }\end{array}$ \\
\hline Patients, $\mathrm{n}$ & 40 & 31 & 20 & $1973>20$ & 110 & 62 & 83 & 18 & 65 & 28 \\
\hline Male/female ratio & 0.67 & 0.8 & 1.0 & 1.0 & 0.6 & 1.1 & 0.8 & 2.0 & 1.0 & 1.08 \\
\hline $\begin{array}{l}\text { Age at disease onset (mean), } \\
\text { years }\end{array}$ & 10.6 & n.r. & $13(0.0-16)$ & n.r. & $11.6 \pm 3.5$ & n.r. & $12.3(1-16)$ & $10.3(1-15)$ & $8.4(0-16)$ & $<16$ \\
\hline \multicolumn{11}{|l|}{ Clinical features, \% } \\
\hline Oral aphthae & 100 & 100 & 100 & 97.8 & 100 & 100 & 100 & 100 & 96.0 & 100 \\
\hline Genital ulcers & 82.5 & 58 & 70 & 64.7 & 82.7 & 55 & 82.0 & 67 & 70.0 & 82 \\
\hline Skin lesions & 72.5 & 55 & 65 & 65.3 & 76.0 & n.r. & n.r. & n.r. & 92.0 & 89 \\
\hline Erythema nodosum & 58.6 & n.r. & n.r. & 19.6 & 37.3 & 26 & 52.0 & 44 & 40.0 & 46 \\
\hline Pseudofolliculitis & 69.0 & n.r. & n.r. & 57.0 & 39.0 & 32 & 51.0 & 50 & 58.0 & 70 \\
\hline Ocular involvement & 27.5 & 29 & 20 & 56.1 & 30.9 & n.r. & 35.0 & 67 & 61.0 & 48 \\
\hline Vascular involvement & 7.0 & n.r. & n.r. & 6.5 & 3.6 & 5 & 9.6 & 11 & 15.0 & 25 \\
\hline Joint involvement & 27.5 & n.r. & 30 & 37.1 & 22.7 & 42 & 40.0 & 61 & 46.0 & 57 \\
\hline CNS involvement & 2.5 & n.r. & n.r. & 10.3 & 3.6 & 13 & 7.2 & 17 & 36.9 & 21 \\
\hline GI lesions & 5.0 & n.r. & 50 & 7.6 & n.r. & n.r. & 4.8 & 11 & 14.0 & 19 \\
\hline Pathergy test & n.r. & n.r. & n.r. & 49.4 & 45.5 & 47 & 37.0 & 22 & 80.0 & 38 \\
\hline Familial incidence & 22.5 & n.r. & 1 & n.r. & 12.3 & 42 & 19.0 & n.r. & 15.0 & 25 \\
\hline
\end{tabular}

GI = Gastrointestinal; CNS = central nervous system; n.r. = not reported.

In several studies, the prevalence of JABD was estimated to be in the range of $2-5 \%$ of all $\mathrm{ABD}$-suffering patients $[4,15,21-23]$. Indicatively, the prevalence of JABD in France has been recorded as $1 / 600,000$ [24]. On the other hand, in Turkey the reported results vary widely: no active $\mathrm{ABD}$ could be detected in a population of 46,816 children [25], while JABD prevalences of less than 0.006 [26], of 0.2 [27], of 5.3 [28] and of $13.4 \%$ [7] among all ABD patients were reported in different Turkish studies. In Germany a JABD rate of $17 \%$ among $168 \mathrm{ABD}$ patients was assessed, $5 \%$ of which met the International Study Group for Behçet's Disease criteria [19] under the age of 16 [6].

\section{Sex Ratio}

The sex ratio is not consistent among the existing studies. Both a male $[10,14,21,28-30]$ and a female $[7,15$, 31] predominance have been registered. Overall, the male-female ratio in JABD is comparable to that in AABD [9].

\section{Familial Incidence}

The familial prevalence among patients with JABD ranges widely from 12 to $15[7,15,30]$ to $22.5-25[6,21]$ and $42-55 \%[13,14,16]$.

\section{Clinical Features of JABD}

\section{Oral Aphthous Ulcers}

Recurrent oral aphthous ulcers are in $70-87 \%$ of the patients the most frequent initial symptom in JABD, followed by skin lesions in 5-15\%, genital lesions in 6\% and ocular findings in $5 \%[7,15,30,32]$ (tables 1-3). However, during the course of the disease, oral aphthous ulcers occur in nearly all patients $[7,11,14,15,21]$. There have been only a few reports with recurrent oral aphtha prevalence of less than $100 \%$ incidence of recurrent aphthae $[29,30]$. The number of attacks, annually, ranges from 1 to 40 [30]. Oral aphthous ulcers have a similar frequency of appearance between boys and girls. The characteristics of the lesions are generally similar to those of AABD patients.

\section{Genital Ulcers}

Recurrent genital ulcers are the second most frequent manifestation in JABD, and their frequency ranges from 58 to $94 \%[7,13,15,21,31,33]$. They usually leave a scar on the involved skin or mucosa [13]. Nevertheless, scarring is less frequent in JABD than in AABD patients [34]. Genital ulcers are more frequent in girls than in boys (50$61 \%$ vs. $75-96 \%)[15,24]$. In boys, they are mostly localized in the scrotum and pubis and rarely in the penis, whereas in girls they appear at the major labiae and rarely in the vagina [13]. Perianal and extragenital ulcers can also be observed [30,33]. 
Table 2. Comparison of clinical features between males and females with JABD (\%)

\begin{tabular}{llll}
\hline & $\begin{array}{l}\text { Atmaca et al. [15], } \\
\text { male/female }\end{array}$ & $\begin{array}{l}\text { Kural-Seyahi et al. [27], } \\
\text { male/female }\end{array}$ & $\begin{array}{l}\text { Koné-Paut et al. [30], } \\
\text { male/female }\end{array}$ \\
\hline Patients, n & 110 & 121 & 65 \\
Country & Turkey & Turkey & France \\
Year of study & 2011 & 2004 & 1998 \\
Male/female ratio & 0.60 & 1.00 & 1.03 \\
Oral aphthae & $100 / 100$ & $100 / 100$ & $96.9 / 96.8$ \\
Genital ulcers & $61 / 95.7$ & $56 / 75$ & $60.6 / 81.2$ \\
Skin manifestations & n.r. & n.r. & $90.6 / 93.7$ \\
Erythema nodosum & $39 / 36.2$ & $48 / 30$ & $40 /-$ \\
Pseudofolliculitis & $41.5 / 37.7$ & n.r. & $58 /-$ \\
Ocular involvement & $48.7 / 20.3$ & $62.3 / 46.7$ & $81.8 / 40.6$ \\
Athritis/joint involvement & $26.8 / 20.3$ & $22 / 21$ & $56 /-$ \\
Vasculitis & $9.8 / 0$ & $20.9 / 0$ & $21.2 / 9.3$ \\
CNS involvement & $9.8 / 0$ & $12.9 / 7$ & $12.1 / 18.7$ \\
Gastrointestinal & n.r. & n.r. & $15.1 / 12.5$ \\
Pathergy test & $43.9 / 46.4$ & n.r. & $80 /-$ \\
Family history & 12.3 & n.r. & n.r. \\
\hline
\end{tabular}

n.r. $=$ Not reported

Table 3. Comparison of clinical manifestations in JABD and AABD (\%)

\begin{tabular}{|c|c|c|c|c|c|}
\hline & $\begin{array}{l}\text { Karincaoglu } \\
\text { et al. [7], J/A }\end{array}$ & $\begin{array}{l}\text { Kural-Seyahi } \\
\text { et al. [27], J/A }\end{array}$ & $\begin{array}{l}\text { Krause } \\
\text { et al. [9], J/A }\end{array}$ & $\begin{array}{l}\text { Vaiopoulos } \\
\text { et al. [32], J/A }\end{array}$ & $\begin{array}{l}\text { Treudler } \\
\text { et al. [6], J/A }\end{array}$ \\
\hline Patients, $\mathrm{n}$ & $83 / 536$ & $121 / 428$ & $19 / 34$ & $18 / 52$ & $28 / 140$ \\
\hline Country & Turkey & Turkey & Israel & Greece & Germany \\
\hline Year & 2008 & 2004 & 1999 & 1999 & 1999 \\
\hline Male/female ratio & $0.8 / 1.2$ & 1.0/n.r. & $0.73 /$ n.r. & 2.0/n.r. & $1.08 / 1.60$ \\
\hline Oral aphthae & $100 / 100$ & $100 / 100$ & $100 / 100$ & $100 / 100$ & $100 / 100$ \\
\hline Genital ulcers & $82 / 86$ & $65 / 95$ & $32 / 87$ & $67 / 79$ & $82 / 76$ \\
\hline Skin lesions & n.r. & n.r. & $90 / 82$ & n.r. & $89 / 86$ \\
\hline Erythema nodosum & $52 / 43$ & $40 / 62$ & $37 / 27$ & $44 / 42$ & $46 / 43$ \\
\hline Pseudofolliculitis & $51 / 56$ & $62 / 83$ & n.r. & $50 / 46$ & $70 / 58$ \\
\hline Ocular involvement & $35 / 30$ & $60 / 47$ & $47 / 47$ & $67 / 75$ & $48 / 67$ \\
\hline Articular involvement & $40 / 34$ & $20 / 39$ & $32 / 71$ arthritis & $61 / 52$ & $57 / 64$ \\
\hline Vascular involvement & $10 / 11$ & $14 / 21$ & $11 / 26$ & $11 / 6$ & $25 / 28$ \\
\hline CNS involvement & $7 / 3$ & $10 / 3$ & $26 / 6$ & $17 / 21$ & $21 / 21$ \\
\hline Gastrointestinal & $5 / 1$ & 0.8/n.r. & $37 / 12$ & $11 / 2$ & $19 / 17$ \\
\hline Epididymitis & n.r. & n.r./n.r. & n.r. & $27 / 11$ & $13 / 21$ \\
\hline Pathergy test & $37.3 / 38$ & n.r./n.r. & $41 / 57$ & $22 / 35$ & $38 / 61$ \\
\hline Family history & $19 / 10.3$ & 19/n.r. & $37 / 35$ & n.r./n.r. & $25 / 8$ \\
\hline
\end{tabular}

$\mathrm{J}=$ Juvenile; $\mathrm{A}$ = adult; n.r. = not reported.

\section{Skin Lesions}

The frequency of skin lesions in JABD ranges from 76 to $92 \%[15,21,29,30]$. The most frequent skin manifestations in JABD are recurrent erythema nodosum and pseudofolliculitis. The determination of a papulopustular lesion, e.g. pseudofolliculitis, as a JABD manifestation is quite a challenge. Erythema nodosum may be found in $18-20 \%[13,29]$ to $40-59 \%$ of the JABD patients $[7,21$, $24]$, i.e. as frequently as in $\mathrm{AABD}[6,32]$. The frequency of pseudofolliculitis ranges from 38 to $69 \%[11,21]$ and is less frequent in JABD than in AABD $[6,7,24]$. Both erythema nodosum and pseudofolliculitis are more fre- 
quent in boys than in girls $[7,15,24]$. Nonfollicular lesions, located in areas other than the face, are considered more characteristic for JABD. Palpable purpura, Sweet's syndrome, pyoderma gangrenosum-like lesions and abscesses have rarely been reported [13].

\section{Eye Involvement}

The frequency of recurrent eye involvement in JABD ranges from 7.5 to $80 \%[9,12,13,15-17,21,25-30,33$, $35]$. In a recent cohort of $3,382 \mathrm{ABD}$ patients, only $3.3 \%$ were younger than 15 years, whereas $31 \%$ of the children had been diagnosed with ocular involvement [15]. The latter may be the initial manifestation in $20 \%$ of JABD patients [36]. In a cohort of 62 JABD patients, $80.7 \%$ developed uveitis at the end of the follow-up period [14]. Ocular involvement is more often found in AABD than JABD patients [6]. Recurrent ocular manifestations can affect either one or both eyes. Eye involvement may last for quite a few weeks. Several studies have shown that panuveitis, associated with retinal vasculitis, is the most prominent type of eye involvement [28]. The prevalence of uveitis in JABD ranges from 0.7 [37] to $14.7 \%$ [28]. Further ocular manifestations include conjunctivitis, papilledema, band keratopathy, retinal vasculitis, retinitis, papillitis, macular edema, hypopyon and ophthalmomalacia $[14,18,30]$. Posterior synechiae, cataract, glaucoma, phthisis bulbi, branch retinal vein occlusion, maculopathy $[14,38]$ and ultimately vision loss to blindness were also reported in $6.3-9 \%[6,30,32]$. Hypopyon was reported in $11-15 \%$ of JABD patients $[14,39]$. A recent relevant review including $130 \mathrm{JABD}$ patients also reported ocular features, i.e. papilledema, optic atrophy, blurry vision and diplopia [17]. Eye inflammation is typically nongranulomatous and affects the anterior, the posterior or both segments [37]. The outcome of ocular manifestations in JABD is better than that in $\mathrm{AABD}[39,40]$ and severe complications, particularly blindness, are less frequent in JABD than in AABD patients (9 vs. 29\%) [6]. However, the JABD incidents should have been observed early enough to clarify their morbidity more accurately. Ocular disease was observed in $47-63 \%$ males and $20-47 \%$ females with JABD [9, 15, $24]$. Boys experience a more severe eye involvement [15, $30,41]$. Anterior uveitis was reported more often in juvenile than in adult patients [35]. Hypopyon was reported in $9 \%$ of JABD patients [15].

\section{Joint Involvement}

The reported arthritis prevalence in JABD varies widely, though in most cases arthralgia and not arthritis occurs. The articular involvement is recurrent, lasts for a few days or weeks and leaves no permanent lesions or joint deformities $[18,32]$. Recurrent arthritis is much less common in JABD that in AABD $[6,9,32]$. Arthritis in JABD is usually an oligoarthritis, which rarely leads to polyarthritis [30]. It manifests at the lower extremities, knees, ankles (rarely elbows), small joints of the fingers and more rarely the sternoclavicular joint $[13,30$, 33].

\section{Neurological Manifestations}

The prevalence of nervous system involvement in JABD patients ranges from 2.5 to $44 \%[7,9,11,14,16,21$, $32,42]$. Neurological symptoms may be the first manifestations of ABD in children [43]. The JABD clinical types are identical to those of AABD. In the former, $14 \%$ of the patients exhibit a parenchymal neuro-ABD, 35\% a nonparenchymal one and the rest a mixed type $[17,44$, 45]. A severe neurological deficit may occur in the parenchymal type. The main clinical manifestations of nonparenchymal involvement with dural sinus thrombosis include headache, nausea, diplopia, subacute hemorrhage and cerebral vasculitis [17]. Other features pertaining to this type are hypertension and seizures while neuropsychotic manifestations are uncommon [46]. The dural sinus thrombosis is more common in JABD patients than in AABD ones whereas the parenchymal type is more common in adults $[11,47,48]$. In a study with 40 JABD patients, 12 of them presented neurological findings (i.e. 5 with cerebral venous thrombosis, 1 with peripheral neuropathy, 1 with transverse myelitis and 1 with psychiatric disturbance) [42]. Rare manifestations include brainstem dysfunction, myelopathy and meningoencephalitis [46]. Recurrent pyramidal signs and diffuse vasculitis have also been reported [32]. The peripheral nervous system can rarely be affected in JABD [30, 42].

\section{Vascular Manifestations}

The prevalence of vascular manifestations in JABD ranges from 3.6 to $21 \%[11,15,49]$. All vessels can be involved, and recurrent aneurysms, stenosis and thrombosis have, thus, been described $[29,49,50]$. Accordingly, pulmonary artery aneurysms (24\%), abdominal aortic aneurysms, aneurysms in the common carotid artery, vena cava thrombosis (18\%), Budd-Chiari syndrome (6\%), superficial thrombophlebitis (18\%), deep vein thrombosis of the lower extremities (37\%), thrombosis of the iliac and femoral arteries and superior sagittal and sinus thrombosis have been reported [24, 30, 34, 51, 52]. It should be noted that the pulmonary artery involvement 
is crucial for prognosis [18]. JABD patients exhibit less frequently vascular involvement than $\mathrm{AABD}$ patients (10.5 vs. 26.5\%) [9], and boys develop venous thrombosis more frequently than girls [30]. The vascular involvement (vasculitis) in ABD is due to vascular inflammation, dysregulation of a number of coagulation factors, elevated levels of $\operatorname{IgG}$ anticardiolipin antibodies and factor $\mathrm{V}$ Leiden mutation $[51,53]$.

\section{Intestinal Manifestations}

A variety of gastrointestinal symptoms have been reported by several investigators. Hemorrhage and perforation are the most frequent manifestations. The prevalence of gastrointestinal involvement in JABD ranges from 5 to $50 \%[11,33]$. Intestinal disease was reported to be more common in JABD than in AABD in Turkey [34]. The intestinal ulcerations in JABD are rare, localized, round and very limited compared to Crohn's disease [54]. The ulcers are localized in the terminal ileum or in the ileocecal region, in the colon and anus [33]. The intestinal involvement is probably more frequent in JABD than in AABD [9].

\section{Orcheoepididymitis}

The prevalence of orcheoepididymitis in JABD is reported to range from 5 to $27 \%[6,29,32,55]$. The frequency of genitourinary symptoms in JABD is altogether similar to that in AABD $[6,32]$. The orcheoepididymitis is usually unilateral [32].

\section{Neonatal ABD}

Only a few reports on neonatal ABD (4 boys and 5 girls) were extracted from the literature [56-62]. The disease started at birth [56,57], at the age of 5 days [58], 10 days [59] or 2 weeks [60]. ABD-diseased mothers, aged from 28 to 38 years, were reported in 8 out of 9 cases $(3$ male and 5 female children) [56-59, 61, 62]. Other children in those families were healthy. Oral ulcers and skin lesions were found in all neonates, 3 of whom further developed genital ulcers and gastrointestinal manifestations, and 4 of them showed fever. The symptoms subsided within 3-9 weeks. Neurological manifestations were reported in a 34-week neonate of a diseased mother and were suspected to be ABD-related; death occurred on the 9th day [63]. A transient incident in a neonatal girl with $\mathrm{ABD}$ of a diseased mother has also been described [64]. On day 1 of life, the neonate presented papulopustular lesions of the labia and perineum.

Juvenile Adamantiades-Behçet Disease
Table 4. Current treatment options in JABD

\begin{tabular}{ll}
\hline Clinical features of JABD & Treatment \\
\hline Oral aphthous ulcers & $\begin{array}{l}\text { Topical corticosteroid cream, } \\
\text { sucralfate, colchicine }\end{array}$ \\
\hline Genital ulcers & Topical corticosteroid cream \\
\hline Skin manifestations & $\begin{array}{l}\text { Colchicine, corticosteroids, } \\
\text { azathioprine }\end{array}$ \\
\hline Joint involvement & $\begin{array}{l}\text { NSAIDs, colchicine, in refractory } \\
\text { cases: azathioprine, anti-TNF- } \alpha \\
\text { agents }\end{array}$ \\
\hline Ocular manifestations & $\begin{array}{l}\text { Topical and systemic corticosteroids, } \\
\text { azathioprine, anti-TNF- } \alpha \text { agents }\end{array}$ \\
\hline CNS manifestations & $\begin{array}{l}\text { Cyclosporine A, intravenous } \\
\text { corticosteroids, cyclophosphamide, } \\
\text { anti-TNF- } \alpha \text { agents }\end{array}$ \\
\hline $\begin{array}{l}\text { Gastrointestinal } \\
\text { manifestations }\end{array}$ & $\begin{array}{l}\text { Sulfasalazine, thalidomide } \\
\text { Vascular manifestations }\end{array}$ \\
$\begin{array}{l}\text { Anticoagulants (contraindicated } \\
\text { when there is the possibility of a } \\
\text { coexisting pulmonary arterial } \\
\text { aneurysm), immunosuppressives }\end{array}$ \\
\hline
\end{tabular}

\section{Pathergy Test}

A positive pathergy test has been observed in 14-80\% of patients with JABD [13, 30, 32, 65]. In most studies the prevalence of the pathergy test ranged from 40 to $50 \%[14,15,29]$. From 6 ABD neonatal cases with reported pathergy test results, 2 had a positive reaction (33\%). The positive pathergy test was found equally likely in both genders. There exists no difference in the prevalence of a positive pathergy test among JABD and AABD cases [7].

\section{Diagnosis}

Specific features of the disease may not exist at the same time, thus rendering the diagnosis of JABD quite difficult. Consequently, a long time lapse may be necessary before the appearance of any characteristic clinical features that would allow a solid diagnosis $[6,65,66]$. In such cases, diagnosis can only be made by an exclusion approach, using the current international criteria [20] as well as those for specific organ involvement [45]. 


\section{Treatment}

As in $\mathrm{AABD}$, mortality rates in JABD are more prominent for males. The armamentarium for JABD treatment is similar, to some extent, to that of AABD (table 4) [6770]. The most frequently prescribed systemic therapy in East/South Asian JABD patients is corticosteroids (42.2\%), followed by cyclophosphamide (20.0\%), methotrexate $(18.9 \%)$, colchicine $(13.3 \%)$, azathioprine $(8.9 \%)$, cyclosporine A (8.1\%) and interferon- $\alpha$ (1.5\%) [71]. Three quarters of the patients were treated with drug combinations. JABD patients in Turkey were treated with colchicine, corticosteroids, cyclosporine A and azathioprine [15]. Treatment with anticoagulants is not widely accepted [72] although these are administered in thrombosis of the central nervous system [45]. Anticoagulants are clearly contraindicated in coexisting pulmonary arterial aneurysm, which may lead to fatal hemorrhage. In selected cases, immunosuppressive drugs, biological agents and thalidomide could be effective [69, 73-78]. In addition, there is an increasing interest in the results pending regarding the effectiveness of anti-IL- 6 and various anti-IL-1 agents.
It is evident that the pediatric community needs to design multicenter studies on the use of new treatments, including biological agents, in JABD.

\section{Acknowledgment}

The authors wish to thank Dr. Petros G. Tsoungas for his constructive comments in the preparation of the present paper.

\section{Statement of Ethics}

No EC approval was required.

\section{Disclosure Statement}

The authors declare no conflict of interest.

\section{References}

1 Kapsimali VD, Kanakis MA, Vaiopoulos GA, Kaklamanis PG: Etiopathogenesis of Behçet's disease with emphasis on the role of immunological aberrations. Clin Rheumatol 2010;29: 1211-1216.

- Bonitsis NG, Luong Nguyen LB, Lavalley M, et al: Gender-specific differences in Adamantiades-Behçet's disease presentation: an analysis of the German Registry for Adamantiades-Behçet's disease and meta-analysis of data from the literature. Rheumatology 2015;54: 121-133.

3 Zouboulis CC, May T: Pathogenesis of Adamantiades-Behçet's disease. Med Microbiol Immunol 2003;192:149-155.

4 Zouboulis CC: Epidemiology of Adamantiades-Behçet's disease. Ann Med Interne 1999; 150:488-498.

5 Kural-Seyahi E, Fresko I, Seyahi N, et al: The long-term mortality and morbidity of Behçet syndrome: a 2-decade outcome survey of 387 patients followed at a dedicated center. Medicine (Baltimore) 2003;82:60-76.

-6 Treudler R, Orfanos CE, Zouboulis CC: Twenty eight cases of juvenile-onset Adamantiades-Behçet's disease in Germany. Dermatology 1999;199:15-19.
7 Karincaoglu Y, Borlu M, Toker SC, et al: Demographic and clinical properties of juvenileonset Behçet's disease: a controlled multicenter study. J Am Acad Dermatol 2008;58: 579-584.

8 Mundy TM, Miller JJ: Behçet's disease presenting as chronic aphthous stomatitis in a child. Pediatrics 1978;62:205-208.

-9 Krause I, Uziel Y, Guedj D, et al: Childhood Behçet's disease: clinical features and comparison with adult-onset disease. Rheumatology (Oxford) 1999;38:457-462.

-10 Sarica R, Azizlerli G, Kose A, Disci R, Ovul C, Kural Z: Juvenile Behçet's disease among 1,784 Turkish Behçet's patients. Int J Dermatol 1996;35:109-111.

11 Koné-Paut I, Gorchakoff-Molinas A, Weschler B, Touitou I: Paediatric Behçet's disease in France. Ann Rheum Dis 2002;61:655-656.

12 Adams EE, Aluquin VP, Bingham CA, Stone JR, Pauliks LB: Cardiac tumor in juvenile onset Behçet's disease: case report and review of the literature. Pediatr Cardiol 2010;31:277279.
13 Borlu M, Uksal U, Ferahbas A, Evereklioglu C: Clinical features of Behçet's disease in children. Int J Dermatol 2006;45:713-716.

14 Sungur GK, Hazirolan D, Yalvac I, et al: Clinical and demographic evaluation of Behçet disease among different paediatric age groups. Br J Ophthalmol 2009;93:83-87.

-15 Atmaca L, Boyvat A, Nilófer Yalcındağ FN, Atmaca-Sonmez P, Gurler A: Behçet disease in children. Ocul Immunol Inflam 2011;19: 103-107.

16 Al Mosawi ZS, Madan W, Fareed E: Pediatriconset Behçet disease in Bahrain: report of nine cases and literature review. Arch Iran Med 2012;15:485-487.

-17 Mora P, Menozzi C, Orsoni JG, Rubino P, Ruffini L, Carta A: Neuro-Behçet's disease in childhood: a focus on the neuro-ophthalmological features. Orphanet J Rare Dis 2013;8: 18.

18 Piram M, Koné-Paut I: Maladie de Behçet de l'enfant. Rev Med Interne 2014;35:121-125.

19 International Study Group for Behçet's Disease: Criteria for diagnosis of Behçet's disease. Lancet 1990;335:1078-1080. 
20 International Team for the Revision of the International Criteria for Behçet's Disease (ITRICBD): The international criteria for Behçet's disease (ICBD): a collaborative study of 27 countries on the sensitivity and specificity of the new criteria. J Eur Acad Dermatol Venereol 2014;28:338-347.

21 Kim D-K, Chang SN, Bang D, Lee E-S, Lee S: Clinical analysis of 40 cases of childhood-onset Behçet's disease. Pediatric Dermatol 1994; 11:95-101.

22 Pivetti-Pezzi P, Accortini M, Abdulaziz MA, et al: Behçet's disease in children. Jpn J Ophthalmol 1995;39:309-314.

23 Schafaie N, Shahram F, Davatchi F, et al: Behçet's disease in children; in Wechsler B, Godeau P (eds): Behçet's Disease. Proceedings of the 6th International Conference on Behçet's Disease. Amsterdam, Excerpta Medica, Elsevier Science Publishers, 1993, pp 381-383.

24 Koné-Paut I, Bernard JL: Behçet disease in children in France. Arch Fr Pediatr 1993;50: 145-154.

25 Ozen S, Karaaslan Y, Ozdemir O, et al: Prevalence of juvenile chronic arthritis and familial Mediterranean fever in Turkey: a field study. J Rheumatol 1998;25:2445-2449.

-26 Yazici H, Biyikli M, van der Linden S, Schouten HJ: The 'zero patient' design to compare the prevalences of rare diseases. Rheumatology (Oxford) 2001;40:121-122.

$\checkmark 27$ Kural-Seyahi E, Ozdogan H, Yurdakul S, et al: The outcome of the children with Behçet's syndrome. Clin Exp Rheumatol 2004;22 (suppl 34):116.

28 Citirik M, Berker N, Songur MS, Soykan E, Zilelioglu O: Ocular findings in childhoodonset Behçet disease. J AAPOS 2009;13:391395.

29 Davatchi F, Shahram F, Chams-Davatchi C, et al: Behçet's disease in Iran: analysis of 6,500 cases. Int J Rheum Dis 2010;13:367-373.

- 30 Koné-Paut I, Yurdakul S, Bahabri SA, Shafae $\mathrm{N}$, Ozen S, Ozdogan H, et al: Clinical features of Behçet's disease in children: an international collaborative study of 86 cases. J Pediatr 1998;132:721-725.

- 31 Fujikawa S, Suemitsu T: Behçet disease in children: a nationwide retrospective survey in Japan. Acta Paediatr Jpn 1997;39:285-289.

- 32 Vaiopoulos G, Kaklamani VG, Markomichelakis N, Tzonou A, Mavrikakis M, Kaklamanis P: Clinical features of juvenile Adamantiades-Behçet's disease in Greece. Clin Exp Rheumatol 1999;17:256-259.

-33 Hung CH, Lee JH, Chen ST, et al: Young children with Behçet disease have more intestinal involvement. J Pediatr Gastroenterol Nutr 2013;57:225-229.

- 34 Seyahi E, Özdoğan H: Juvenile Behçet's syndrome; in Yazici Y, Yazici H (eds): Behçet's syndrome. Berlin, Springer Science + Business Media, 2010, chapt 12, pp 205-214.
35 Kramer M, Amer R, Mukamel M, Snir M, Jaouni T, Friling R: Uveitis in juvenile Behçet's disease: clinical course and visual outcome compared with adult patients. Eye (Lond) 2009;23:2034-2041.

36 Reiff A, Kadayifcilar S, Özen S: Rheumatic inflammatory eye diseases of childhood. Rheum Dis Clin N Am 2013;39:801-832.

37 Tugal-Tutkun I, Havrlikova K, Power WJ, Foster CS: Change in patterns in uveitis of childhood. Ophthalmology 1996;103:375383.

38 Kesen MR, Goldstein DA, Tessler HH: Uveitis associated with pediatric Behçet disease in the American Midwest. Am J Ophthalmol 2008;146:819-827.

39 Tugal-Tutkun I, Urgancioglu M: Childhoodonset uveitis in Behçet disease: a descriptive study of 36 cases. Am J Ophthalmol 2003;136: 1114-1119.

40 Friling R, Kramer M, Snir M, Axer-Siegel R, Weinberger D, Mukamel M: Clinical course and outcome of uveitis in children. J AAPOS 2005;9:379-382.

41 Tugal-Tutkun I, Onal S, Altan-Yaycioglu R, Altunbas H, Urgancioglu M: Uveitis in Behçet disease: an analysis of 880 patients. Am J Ophthalmol 2004;138:373-380.

42 Metreau-Vastel J, Mikaeloff Y, Tardieu M, Koné-Paut I, Tran TA: Neurological involvement in paediatric Behçet's disease. Neuropediatrics 2010;41:228-234.

43 Cakar N, Başaran O, Uncu N, et al: Clinical characteristics of paediatric neuro-Behçet's disease: a single tertiary centre experience. Clin Exp Rheumatol 2014;32(suppl 84):S165S170.

44 Akman-Demir G, Serdaroglu P, Tasçi B: Clinical patterns of neurological involvement in Behçet's disease: evaluation of 200 patients. The Neuro-Behçet Study Group. Brain 1999; 122:2171-2182.

45 Kalra S, Silman A, Akman-Demir G, et al: Diagnosis and management of Neuro-Behçet's disease: international consensus recommendations. J Neurol 2014;261:1662-1676.

46 Panicker JN, Vinayan KP, Ahsan Moosa NV, Elango EM, Kumar AA: Juvenile Behçet's disease: highlighting neuropsychiatric manifestations and putative genetic mechanisms. Clin Neurol Neurosurg 2007;109:436-438.

47 Siva A, Kantarci OH, Saip S, et al: Behçet's disease: diagnostic and prognostic aspects of neurological involvement. J Neurol 2001;248: 95-103.

48 Bahabri SA, al-Mazyed A, al-Balaa S, el-Ramahi L, al-Dalaan A: Juvenile Behçet's disease in Arab children. Clin Exp Rheumatol 1996; 14:331-335.

49 Ozen S, Bilginer Y, Besbas N, Ayaz NA, Bakkaloglu A: Behçet disease: treatment of vascular involvement in children. Eur J Pediatr 2010;169:427-430.

-50 Antar KA, Keiser HD, Peeva E: Relapsing arterial aneurysms in juvenile Behçet's disease. Clin Rheumatol 2005;24:72-75.
1 Beşbaş N, Ozyürek E, Balkanci F, et al: Behcet's disease with severe arterial involvement in a child. Clin Rheumatol 2002;21:176-179.

52 Tuzuner A, Uncu H: A case of Behçet's disease with an abdominal aortic aneurysm and two aneurysms in the common carotid artery. A case report. Angiology 1996;47:1173-1180.

53 Kalayciyan A, Zouboulis CC: An update on Behçet's disease. J Eur Acad Dermatol Venereol 2007;21:1-10.

54 Lee SK, Kim BK, Kim TI, Kim WH: Differential diagnosis of intestinal Behçet's disease and Crohn's disease by colonoscopic findings. Endoscopy 2009;41:9-16.

55 Uziel Y, Brik R, Padeh S, Barash J, Mukamel M, Harel L, Press J, Tauber T, Rakover Y, Wolach B: Juvenile Behçet's disease in Israel. The Pediatric Rheumatology Study Group of Israel. Clin Exp Rheumatol 1998;16:502-505.

56 Lewis MA, Priestley BL: Transient neonatal Behçet's disease. Arch Dis Child 1986;61: 805-806.

57 Fain O, Mathieu E, Lachassinne E, et al: Neonatal Behçet's disease. Am J Med 1995;98: 310-311.

58 Stark AC, Bhakta B, Chamberlain MA, Dear P, Taylor PV: Life-threatening transient neonatal Behçet's disease. Br J Rheumatol 1997; 36:700-702.

59 Chang YS, Yang YH, Chiang BL: Neonatal Behçet's disease without maternal history. Clin Rheumatol 2011;30:1641-1645.

60 Wu PS, Chen HL, Yang YH, Jeng YM, Lee PI, Chang MH: Intestinal Behçet disease presenting as neonatal onset chronic diarrhea in an 11-month-old male baby. Eur J Pediatr 2005; 164:523-525.

61 Fam AG, Siminovitch KA, Carette S, From L: Neonatal Behçet's syndrome in an infant of a mother with the disease. Ann Rheum Dis 1981;40: 509-512.

62 Thivolet J, Cambazard F, Genvo MF: Maternally transmitted severe neonatal aphthosis. Ann Dermatol Venereol 1982;109:815-816.

63 Jog S, Patole S, Koh G, Whitehall J: Unusual presentation of neonatal Behçet's disease. Am J Perinatol 2001;18:287-292.

-64 Antonelou M, Braha N: Transient neonatal Behçet's disease. BMJ Case Rep 2013;2013.

- 65 De Albuquerque PR, Terreri MT, Len CA, Hilário MO: Behçet's disease in childhood. J Pediatr (Rio J) 2002;78:128-132.

66 Choi JY, Park SY, Hwang IO, Lee YH: NeuroBehçet disease presented diplopia with hemiparesis following minor head trauma. Korean J Pediatr 2012;55:354-357.

67 Zouboulis CC: Adamantiades-Behçet's disease; in Katsambas AD, Lotti T, Dessinioti C, D'Erme AM (eds): European Handbook of Dermatological Treatments, ed 3. New York, Springer, 2015, pp 33-44.

68 Bonitsis NG, Altenburg A, Krause L, Stache T, Zouboulis CC: Current concepts in the treatment of Adamantiades-Behçet's disease. Drugs Fut 2009;34:749-763. 
69 Hatemi G, Silman A, Bang D, et al: EULAR recommendations for the management of Behçet disease. Ann Rheum Dis 2008;67: 1656-1662.

70 Hatemi G, Silman A, Bang D, et al: Management of Behçet disease: a systematic literature review for the European League against Rheumatism evidence-based recommendations for the management of Behçet disease. Ann Rheum Dis 2009;68:1528-1534.

-71 Kitaichi N, Miyazaki A, Stanford MR, Iwata D, Chams H, Ohno S: Low prevalence of juvenile-onset Behçet's disease with uveitis in East/South Asian people. Br J Ophthalmol 2009;93:1428-1430.
2 Ozen S, Eroglu FK: Pediatric-onset Behçet disease. Curr Opin Rheumatol 2013;25:636642.

73 Sfikakis PP, Theodossiadis PG, Katsiari CG, Kaklamanis P, Markomichelakis NN: Effect of infliximab on sight-threatening panuveitis in Behçet's disease. Lancet 2001;358:295-296.

74 Sfikakis PP, Markomichelakis N, Alpsoy E, et al: Anti-TNF therapy in the management of Behçet's disease - review and basis for recommendations. Rheumatology (Oxford) 2007; 46:736-741.

75 Ugurlu S, Ucar D, Seyahi E, Hatemi G, Yurdakul S: Canakinumab in a patient with juvenile Behçet's syndrome with refractory eye disease. Ann Rheum Dis 2012;71:1589-1591.
6 Sfikakis PP, Kaklamanis P, Elezoglou A, et al: Infliximab for recurrent, sight-threatening ocular inflammation in Adamantiades-Behcet disease. Ann Intern Med 2004;140:404406.

77 Arida A, Fragiadaki K, Giavri E, Sfikakis PP: Anti-TNF agents for Behçet's disease: analysis of published data on 369 patients. Semin Arthritis Rheum 2011;41:61-70.

78 Yasui K, Misawa Y, Shimizu T, Komiyama A, Kawakami T, Mizoguchi M: Thalidomide therapy for juvenile-onset entero-Behçet's disease. J Pediatr 2003;143:692-694. 